\title{
SONDAŻE WYBORCZE - SOCJOLOGIA W SŁUŻBIE POLITYKI
}

\begin{abstract}
Przed każdymi wyborami jesteśmy inspirowani badaniami wyborczymi, mówiącymi nam który, kandydat albo który partia ma właściwe poparcie. Nie wszyscy Polacy analizują metodologiczne właściwości, związane $\mathrm{z}$ odpowiednio dobraną próbą czy poprawnie skonstruowanym kwestionariuszem ankiety. Błędy popełnia się również za granicą, było ich stosunkowo niewiele, a z roku na rok widoczny jest coraz większy profesjonalizm. Poglądy polityczne badaczy, socjologów nie były jednostronne i wymykały się jednoznacznej ocenie. We współczesnych społeczeństwach o zróżnicowanych systemach światopoglądowych, rozwijają się i uzupełniają rozmaite poglądy oraz oceny, dlatego też opinia publiczna nie jest wielkością jednolitą i trwałą, stałą, lecz zróżnicowaną i zmienną. Spotykamy się także z pojęciem manipulacja, czyli kierowanie kimś bez jego wiedzy; posługiwanie się kimś lub czymś dla osiągnięcia określonych celów; nieuczciwe posługiwanie się przekazem w celu wywarcia określonego wpływu na ludzi, np. przez świadome używanie wyrażeń niejasnych lub niejednoznacznych. Pojawia się też kwestia kłamstwa ankietowanych wyborców. Sondaże są postrzegane jako narzędzie opresji reżimowego państwa. Poziom zaufania Polaków do państwa jest bardzo niski, a jako społeczeństwo mamy też bardzo niską samoocenę.

Badacze tacy jak Ryszard Dyoniziak próbowali nakreślić, najczęstsze błędy ośrodków sondażowych takie jak; koncentrowanie się w badaniach sondażowych na sprawach nieistotnych, ciekawostki a odwracanie uwagi od spraw o podstawowym znaczeniu dla społeczeństwa, narzucanie badanym swojej wizji problemu, stereotypy przyjmowane $\mathrm{w}$ wielu badaniach, skonstruowana struktura pytań, gdzie z góry można przewidzieć zasugerowaną pytaniem odpowiedź, błąd bezzasadnego porównywania, błąd wymuszania pożądanych skojarzeń oraz nieuprawnionych porównań i komentarzy. Socjologowie zaobserwowali też wiele zmian preferencji politycznych, takich jak zjawisko charakteryzujące się tym, że wyborcy kierując się wynikami sondaży, przenoszą swe głosy na sondażowego lidera, czy też sprzyjające wyraźnie słabszemu kandydatowi, gdyż efekt ten charakteryzuje przenoszenie głosów na osobę o niskim poparciu w sondażach.

Słowa kluczowe: polityka, socjolodzy, opinia publiczna, sondaże
\end{abstract}

\section{ZAGRANICZNE ZMAGANIA Z OPINIĄ PUBLICZNA}

Pierre Bourdieu zauważył, że opinia publiczna nie istnieje ${ }^{2}$ : „Podstawowy cel sondażu to: stworzyć ideę, że istnieje jednomyślna opinia publiczna, a więc legitymizować daną politykę i wzmocnić stosunek sił, który ją tworzy lub umożliwia. Krótko mówiąc, chciałem powiedzieć, że opinia publiczna nie istnieje. W każdym razie w tej postaci, jaką

${ }^{1}$ Dr Krzysztof Prendecki, Zakład Nauk Humanistycznych, Wydział Zarządzania, Politechnika Rzeszowska, al. Powstańców Warszawy 8, 35-959 Rzeszów, e - mail: prend@prz.edu.pl

${ }^{2}$ Exposé wygłoszone w styczniu 1972 r. w Centrum Kultury Noroit w Arras. Opublikowane w „Les Temps Modernes” (1973/318, s. 1292-1309), tłum. A. Rybińska. Polska wersja tekstu dostępna w Czytelni „Nowej Konfederacji”. 
przypisują jej ci, którzy mają w tym żywotny interes. [...] Istnieje część opinii już ukonstytuowanych, zmobilizowanych oraz grupy nacisku powstałe wokół wyraźnie określonego systemu interesów. I z drugiej strony, dyspozycje, które z definicji nie są opinią. [...] Mówię po prostu, że opinia publiczna, uznana przez tych, którzy realizują sondaże, czy tych, którzy używają ich wyników, ta opinia publiczna najzwyczajniej nie istnieje".

Elizabeth Noelle-Neumann sformułowała teorię spirali milczenia na początku lat siedemdziesiątych $\mathrm{XX}$ wieku³ ${ }^{3}$ Mechanizm działania spirali milczenia można streścić, wskazując pokrótce na jego podstawowe czynniki stanowiące etapy rozwojowe ${ }^{4}$ :

„1. Pod wpływem informacji dostarczonych przez media ludzie uznają wagę danej kwestii i wyrabiają sobie pogląd na nią, co umożliwia im publiczne zajęcia stanowiska tzn. opowiedzenia się po stronie zwolenników lub przeciwników jakiegoś jej rozwiązania.

2. Ludzie starają się poznać rozkład opinii publicznej, a zwłaszcza dominujący «klimat opinii», czyli co sądzi większość.

3. Gotowość do publicznego wyrażenia swojego poglądu zmienia się zgodnie z tym, jak jednostka postrzega rozkład opinii oraz kierunek jej ewolucji.

4. Wpływ mediów masowych na postrzeganie rozkładu i kierunku ewolucji opinii publicznej rośnie wtedy, gdy spełniają one trzy warunki: daną opinię zgodnie przedstawiają jako dominującą (konsonans), informacje na ten temat pojawiają się $\mathrm{w}$ mediach częściej niż zwykle, dochodzi do ciągłej kumulacji tych informacji.

5. Obawiając się, że publiczne ujawnianie poglądu odmiennego od opinii dominującej może narazić jednostkę na negatywne reakcje ze strony innych ludzi czy wręcz społeczną izolację w jej środowisku, jednostka całkowicie traci ochotę do publicznego ujawniania swojego stanowiska w danej kwestii, a nawet unika rozmów, które mogłyby ją do tego prowokować.

6. Faktyczne wyciszenie poglądów odmiennych od dominującego media przedstawiają jako potwierdzenie tezy o sile i powszechności dominującej opinii publicznej”.

Noam Chomsky stwierdził: „Kluczowym elementem kontroli społeczeństwa jest strategia polegająca na odwróceniu uwagi publicznej od istotnych spraw i zmian dokonywanych przez polityczne i ekonomiczne elity, poprzez technikę ciągłego rozpraszania uwagi i nagromadzenia nieistotnych informacji. Strategia odwrócenia uwagi jest również niezbędna, aby zapobiec zainteresowaniu społeczeństwa podstawową wiedzą z zakresu nauki, ekonomii, psychologii, neurobiologii i cybernetyki. Opinia publiczna odwrócona od realnych problemów społecznych, zniewolona przez nieważne sprawy"5.

Obywateli czy wyborców zastanawia pytanie ${ }^{6}$ : czemu mnie nigdy nie wybrano do badania? Georgie Gallup, założyciel najbardziej prestiżowego ośrodka badania opinii publicznej na świecie, mawiał: „Szybciej trafi Cię piorun, niż znajdziesz się wylosowanej próbie do naszych badań"7. Nie wszyscy jednak dorośli do badań. W Stanach

\footnotetext{
${ }^{3}$ Zob. E. Noelle-Neumann, Spirala milczenia, Poznań 2004.

${ }^{4} \mathrm{http}: / /$ ninawinczewska.blox.pl/2014/07/Teoria-spirali-milczenia.html (dostęp: 12.11.2014).

${ }^{5}$ http://3obieg.pl/manipulacja-wg-chomskyego (dostęp: 15.12.2014).

${ }^{6}$ Por. J. Stecko, Kultura zaufania jako fundament spotecznego życia etycznego [w:] Zaufanie w życiu publicznym, (pod red.) Władysław Zuziak, Joanna Mysona Byrska, s.163-174, Kraków 2014. ${ }^{7}$ Wśród „niedowiarków” pojawił się Władysław Bartoszewski: „Za długo na tym świecie żyję, żeby ślepo wierzyć przedwyborczym sondażom. Dlaczego ani ja, ani moja żona, ani mój syn, ani nikt z moich znajomych w ciągu piętnastu lat nie dostąpił tej łaski bycia zapytanym przez szanownych
} 
Zjednoczonych zadano ankietowanym pytanie: „Czy uważasz, że Statut Spraw Publicznych dobrze spełnia swoją funkcję?” Przeszło 30\% respondentów odpowiedziało tak, mimo że taki statut jeszcze nie powstał.

Błędy popełniane za granicą (było ich stosunkowo niewiele, a z roku na rok widoczny jest coraz większy profesjonalizm) to między innymi:

1. Francja. W roku 2002 lider Frontu Narodowego, Jean-Marie Le Pen, wszedł do drugiej tury wyborów prezydenckich, co zaskoczyło wszystkich obserwatorów politycznych i ośrodki badań opinii publicznej. Dlatego też podczas kolejnych wyborów w 2007 r. Francuzi stali się bardziej powściągliwi, jeśli chodzi o ufność w rezultaty sondaży. Przed kolejnymi wyborami każdego dnia w mediach pojawiało się kilkanaście badań realizowanych przez ośrodki, instytuty i portale internetowe.

2. Wielka Brytania. W 1992 r. najważniejsze firmy sondażowe przewidywały zwycięstwo Partii Pracy o 0,8\%. Jak się okazało, wygrała niefaworyzowana Partia Konserwatywna o 7,5\%. W Parlamencie powołano specjalną komisję badającą sondażowe błędy, związane głównie z doborem próby i nieprzyznawaniem się wyborców do swoich poglądów.

3. Ukraina. W 2004 r. na początku kampanii Wiktor Juszczenko ponad wszelką wątpliwość przewodził w sondażach. Kilka tygodni przed wyborami notowania obu głównych kandydatów się wyrównały. Oficjalny wzrost notowań Wiktora Janukowycza, miał przemówić do niezdecydowanych wyborców, na kogo jedynie słusznie warto glosować. Profesot Bohdan Hud z Uniwersytetu Lwowskiego przytoczył w związku z tą sytuacją powiedzenie o kłamstwach, wielkich kłamstwach i badaniach sondażowych.

4. Słowacja. W 2004 r. podczas wyborów prezydenckich na Słowacji w drugiej turze zmierzyli się Vladimir Mecziar i Ivan Gaszparovicz. Do decydującego finału nie zakwalifikował się uważany za faworyta sondaży Eduard Kukan. Zajął on trzecie miejsce z 22,1\% głosów. Wcześniejsze sondaże opinii publicznej pokazywały, że ma być zdecydowany zwycięzcą.

W 2014 r. Robert Fico był we wszystkich sondażach bezapelacyjnym faworytem. Do drugiej tury przeszli Robert Fico i Andrej Kiska. W drugiej turze zwyciężył Andrej Kiska, zdobywając 59,38\%, a Robert Fico otrzymał 40,61\% głosów.

5. Białoruś. W 2010 r. odbyły się wybory na Białorusi. Wygrał je dotychczasowy prezydent Aleksander Łukaszenka, uzyskując wynik 79,67\%. Oficjalne sondaże odnotowywały 71-procentowe poparcie dla prezydenta Aleksandra Łukaszenki. Ukraiński TNS, który przeprowadzał badania na Białorusi, informował, że urzędujący prezydent ma 55-procentowe poparcie. Ośrodek badawczy NISEPI z Litwy zaś odnotowywał poparcie dla Łukaszenki rzędu 48\%. Międzynarodowy Ośrodek SOCIUM ogłosił, że poparcie dla prezydenta wynosi $35 \%$.

Można zaobserwować również bardzo radykalne działania i zakazy robienia sondaży ${ }^{8}$, tak jak dzieje się to w Iranie, w Chinach, na Kubie czy w Korei Północnej. Fałszowanie danych i dostarczanie informacji Gallupowi to były zarzuty dla irańskich badaczy, których w 2003 r. skazano na długoletnie kary więzienia za opublikowanie wyników sondażu, z

ankieterów, jakie są nasze preferencje polityczne?” (W. Bartoszewski, Za dtugo żyję na tym świecie, żeby ślepo wierzyć przedwyborczym sondażom, „Dziennik” 6.10.2007, s. 19).

${ }^{8} \mathrm{~W}$ sprawie embarga na robienie sondaży wyborczych w Polsce - zob. A. Sułek, Walka o wolność publikacji wyników sondaży wyborczych w Polsce, ,Przegląd Socjologiczny” LVI/1 (2007), s. 9-30. 
którego wynikało, że trzy czwarte mieszkańców Teheranu chce współpracy ze Stanami Zjednoczonymi.

Są natomiast kraje, które miały szczególne problemy z własną historią i próbowały się oczyszczać. W Rumunii CNSAS Narodowa Rada ds. Badania Archiwów Securitate wykazała, że Dorel Abraham, były dyrektor Instytutu Badania Opinii Publicznej, oraz Dumitru Sandu, współpracownik tego instytutu, pisywali raporty dla Securitate. Tematyka obejmowała własne środowisko zawodowe ${ }^{9}$.

\section{SOCJOLODZY W POLSCE ZAANGAŻOWANI POLITYCZNIE DAWNIEJ I DZIŚ}

Szczegółowe opracowanie dorobku polskiej socjologii z lat 1945-1989 nie zostało dokonane, wciąż jeszcze w Polsce jest to wstydliwy temat ${ }^{10}$. Niestety do tej pory odbyła się tylko jedna konferencja na temat socjologii polskiej po II wojnie światowej. Dla dobra zainteresowanych, by nie musiano się wstydzić swych poczynań, nie opublikowano, choć zwyczajowo się to czyni, wygłoszonych referatów ${ }^{11}$.

Poglądy polityczne socjologów nie były jednostronne i wymykały się jednoznacznej ocenie. Występowali przedstawiciele nauk społecznych, którzy gloryfikowali i uwierzyli w panujący system, ale byli też tacy, którzy nie godzili się na zastane porządki, co często skutkowało problemami w pracy. Dyoniziak wspomina o badaczach mających własną autonomię, oportunistach i nadgorliwcach leninowsko-marksistowskich. Kazimierz Staszewski, wieloletni student socjologii na Uniwersytecie Warszawskim, wspomina: „Metodologię wykładał mi najlepszy z najlepszych - nieżyjący już profesor Stefan Nowak. Panie profesorze, to co, wojna? My do niego dzień po ogłoszeniu stanu wojennego. «Dla mnie wojna zaczęła się 17 września 1939 i trwa do dziś» - on nam na to" 12 .

Jacek Kurczewski wraca pamięcią do tamtego okresu: „Kilkadziesiąt lat temu pewien młody student socjologii upierał się z całą powagą w trakcie sesji poświęconej socjologii zaangażowanej, że zaangażowanie może też objawiać się w humorze, który pozwala rozbić fasadę życia społecznego. Patronujący tej debacie opiekun naukowy socjologicznej młodzieży, nie wykluczając i takiego zaangażowania, przypomniał z uśmiechem, że za zaangażowane uchodzą niewiasty, które mają już swoich ustalonych adoratorów. Był humor, ale była też debata na serio. Może było inaczej, kto dziś pamięta te dawne dysputy, ale tłumaczy to, że uwagi o socjologii zaangażowanej Zygmunta Baumana traktuję jako element życiowego dialogu z rzeczywistością"13.

\footnotetext{
${ }^{9}$ Po obaleniu reżimu komunistycznego naukowcy nadal zasiadali w kierownictwie agencji badania opinii publicznej.

${ }^{10}$ R. Dyoniziak, Dylematy upaństwowionej socjologii, „Akademia Ekonomiczna w Krakowie. Zeszyty Naukowe" 2001/566, s. 5.

${ }^{11}$ Ibidem. Wśród analiz warto zwrócić uwagę na publikację: J. Bielecka-Prus, Społeczne role socjologów w PRL, „Przegląd Socjologiczny” 2/58 (2009), s. 71-103.

${ }^{12}$ K. Staszewski, Sondażomania, w: idem, Niepiosenki, Warszawa 2008, s. 471.

${ }^{13}$ J. Kurczewski, Bauman optymista, „Gazeta Wyborcza” 22.11.2010.
} 
W latach 1949-1957 socjologii i sondażowych badań opinii publicznych oficjalnie w PRL nie było ${ }^{14}$. Z polemiki, jaką podjął w 1955 r. Stefan Żółkiewski (1955) z Józefem Chałasińskim, że jedyna sensowna dla nauk społecznych metodologia ma charakter marksistowsko-leninowski ${ }^{15}$. Cenzura w latach sześćdziesiątych nie pozwała na obiektywne badania. W najbardziej bezpośredniej formie przejawiała się w kontrolowaniu treści kwestionariuszy i wykreślaniu z nich terminów i zwrotów uznawanych za nieprawomyślne ${ }^{16}$. Konsekwencje istnienia cenzury były jednak głębsze - skłaniały na przykład badaczy do podejmowania tylko takich tematów badawczych, które miały szansę na publikacje ${ }^{17}$.

W omawianym temacie w dyskusji wzięli udział między innymi socjologowie: Andrzej Flis, Edmund Mokrzycki, Jerzy Szacki, Piotr Sztompka. Przyznajemy, że pojawiły się systematyczne błędy w metodach postępowania badaczy społecznych w przeszłości oraz że wielu z nich przybierało maskę obiektywności, by trwać przy swoich subiektywnych poglądach ${ }^{18}$. Wobec wielkiego zapotrzebowania na badania „fuszerkę" uprawiają czasem i socjologowie $\mathrm{z}$ prawdziwego zdarzenia, biorąc udział $\mathrm{w}$ badaniach wykonywanych na marginesie swoich właściwych zajęć i nie wkładając w nie wiele wysiłku $^{19}$. Przede wszystkim jest to domena różnych pół- i ćwierćsocjologów, którzy umiejętności zastępują tupetem ${ }^{20}$.

Od 1958 r. działał przy Radiokomitecie Ośrodek Badania Opinii Publicznej (OBOP). Jak na ówczesny blok socjalistyczny była to nowość. Czy badania OBOP były wiarygodne? Mało kto się tą kwestią zajmował ${ }^{21}$. Badań mieli nie fałszować, tylko co najwyżej - na otarcie łez - opatrzyli często niezbyt miłe dla władz wyniki jakimiś optymistycznymi wynikami ${ }^{22}$.

Po wprowadzeniu w Polsce stanu wojennego działał też Zespół Partyjnych Socjologów przy KC PZPR, którzy parali się zaleceniami dla socjologów. Członkowie spełniali też funkcje cenzorskie wobec swoich kolegów socjologów (zwłaszcza bezpartyjnych), pisząc poufne recenzje wydawnicze ich prac ${ }^{23}$.

W roku 1982 interesujący się sondażami gen. Wojciech Jaruzelski powołał do życia rządową placówkę badawczą - Centrum Badania Opinii Społecznej (CBOP). Pod przywództwem Stanisława Kwiatkowskiego, który był zdania, że badania opinii

\footnotetext{
${ }^{14}$ J. Lisek-Michalska, Wybrane problemy sondażowych badań opinii publicznej w Polsce w okresie przełomu ustrojowego, w: Analizy i próbki technik badawczych w socjologii, Sondaże opinii społecznej. Samowiedza wspótczesnych społeczeństw, red. Z. Gostkowski, P. Daniłowicz, t. X, Łódź 2001, s. 20.

${ }^{15}$ Ibidem.

${ }^{16}$ Ibidem, s. 21.

${ }^{17}$ Ibidem.

${ }^{18}$ A. Flis, Wyzwania wobec nauk społecznych, Kraków 1999, s. 95.

19 J. Szczepański, Socjologia a fuszerka socjologiczna, ,Przegląd Kulturalny” 1960/13, cyt. za: Publicystyczny komentarz socjologów. Analiza. Polemiki. Wywiady, red. H. Domański, A. Ostrowska, Warszawa 2006, s. 98.

${ }^{20}$ Ibidem.

${ }^{21}$ K. Bachmann, Utajnione ankiety, Dole i niedole OBOP, Pomocnik historyczny, ,, Polityka” 16.08.2008/33, s. 42.

${ }^{22}$ Ibidem.

${ }^{23}$ Zob. H. Galus, Rola socjologii nauki i polityki w życiu publicznym, Gdańsk 2007.
} 
publicznej zawsze będą narzędziem władzy. Rządzący w połowie lat osiemdziesiątych, mogli się dowiedzieć, że społeczeństwo jest opozycyjne w kilku procentach. W roku 1988 informowano natomiast w gazetach, że społeczeństwo jest za likwidacją Stoczni Gdańskiej. Co trzeci ankieter należał do PZPR, do tego często respondentami byli znajomi z bliskiej opcji, a struktura opierała się na wojskowych pracowniach psychologicznych. Przed wyborami w roku 1989 CBOS zadał pytanie: „Na kogo chcesz głosować?”. Jedną z możliwych opcji była odpowiedź: „Na najlepszego kandydata”. Co zinterpretowano jako na nas - rządzących. Prezes CBOS bronił się, podając, że nawet Radio Wolna Europa z radością wygłosiło podziękowania dla dyrektora CBOS"24. Antoni Sułek dowodził: „porównałem wyniki badań rządowego CBOS i akademickiego Instytutu Filozofii i Socjologii. Okazało się, że surowe wyniki tych badań faktycznie różnią się od siebie, ale tylko w kwestiach drażliwych politycznie" ${ }^{25}$.

Badacz klasy robotniczej Leszek Gilejko rozpamiętywał sytuację, w której prowadził badania robotników 1977 r. Pojawiły się donosy do Komitetu Centralnego ze strony dyrektorów przedsiębiorstw czy sekretarzy partii. Dzwoniono i informowano, że ,przyszli jacyś i pytają się o strajki”. Uzyskał zgodę na dalsze badania, pod warunkiem że pierwsze o wynikach dowie się KC.

Najbardziej oczywistą manipulacją ${ }^{26}$ jest takie sformułowanie pytania, by odpowiedź była zgodna $\mathrm{z}$ oczekiwaniami pytającego ${ }^{27}$. Może warto tu przypomnieć słynne „konsultacje społeczne” z czasów PRL ${ }^{28}$. Na przykład w latach osiemdziesiątych zapytano ludzi, czy lepsze są przyspieszenia reform i pogorszenie warunków życia, czy powolne, rozważne reformy prowadzone tak, by warunki życia nie uległy pogorszeniu ${ }^{29}$. (...) Wyniki tego szczególnego referendum były oczywiste - ludzie nie chcieli pogorszenia warunków i tak wówczas trudnego życia. Interpretacja dokonana przez usłużnych ekspertów była też oczywista: społeczeństwo nie popiera opozycji ${ }^{30}$.

Krystyna Lutyńska, opisując wady pytań kwestionariuszowych, analizowała 430 kwestionariuszy, w których znalazła między innymi następujące błędy ${ }^{31}$ :

- $\quad$ pytanie ,Jeśli ludzie mogliby wybierać miejsce swojego życia, to jak P. sądzi, czy częściej wybieraliby kraje socjalistyczne czy kapitalistyczne?”. Można przypuszczać, że ze względu na silne wpajanie w naszym społeczeństwie i rozpowszechnione przekonanie, między innymi w przekazach propagandowych o „wyższości ustroju socjalistycznego nad kapitalistycznym", w bardzo wielu, jeśli nie w większości przypadków, padałyby odpowiedzi „kraje socjalistyczne”;

- czasami pytania kwestionariuszowe mogą wywołać silne emocje lęku, obawy oraz zaskoczenia i niepewności „,o się za tym kryje”. Na przykład „Polska jest krajem

\footnotetext{
${ }^{24}$ Zob. S. Kwiatkowski, Szkicownik z CBOS-u: Rysunki socjologiczne z tamtych lat, Tyczyn 2004.

${ }^{25}$ A. Sułek, Ogród metodologii socjologicznej, Warszawa 2002, s. 44.

${ }^{26}$ Zob. Sommer H., Komunikowanie się $w$ przedsiębiorstwie, Zeszyty Naukowe Politechniki

Rzeszowskiej, Ekonomia i Nauki Humanistyczne, z. 14, nr 219, 2004; s. 167-185.

${ }^{27}$ M. Iłowiecki, Krzywe zwierciadło. O manipulacji w mediach, Lublin 2003, s. 62.

${ }^{28}$ Ibidem.

${ }^{29}$ Ibidem.

${ }^{30}$ Ibidem.

${ }^{31}$ K. Lutyńska, Wywiad kwestionariuszowy. Przygotowanie i sprawdzanie narzędzia badawczego, Warszawa 1984, s. 116-121.
} 
socjalistycznym - czy chciałby P. żeby socjalizm rozpowszechnił się także w innych krajach czy też raczej to nie jest potrzebne?";

- $\quad$ sugerowanie respondentowi odpowiedzi odbywa się też w sposób mniej widoczny, a mianowicie $\mathrm{z}$ pośrednictwem umieszczenia w pytaniu określonych sądów czy terminów, które podpowiadają mu kierunek odpowiedzi: „Co powinno zrobić kierownictwo kraju, aby nadal polepszały się warunki życia w kraju? W naszym kraju w okresie po II wojnie światowej dokonał się wielki postęp pod każdym względem. Jak P. ocenia? Co zdaniem P. ma największe znaczenie dla dalszego pomyślnego rozwoju naszego kraju?"

Przemiany ustrojowe istotnie wpłynęły na postrzeganie badań, autorów i socjologów, którzy je przedstawiają w środkach masowego przekazu. Można wskazać kilka typów socjologów medialnych ${ }^{32}$ :

- ,polityk” - zaangażowany formalnie w działalność polityczną, pełniący funkcje polityczne;

- „ „guru” - intelektualny autorytet, najczęściej jednak tylko dla członków jakiejś partii czy jej zwolenników;

- „partyjny” - zaangażowany w działalność na rzecz jakiejś partii czy opcji ideologicznej w sposób jawny, zadeklarowany, ale częściej prezentujący się jako niezależny, bezstronny ekspert;

- „człowiek odrodzenia” - specjalista od wszelkich spraw społecznych, dyżurny komentator - ,socjolog na telefon”.

Wśród socjologów, którzy uczestniczyli w życiu politycznym lub też mieli istotny wpływ, warto wymienić między innymi ${ }^{33}$ :

- Jacek Kurczewski - w latach 1991-1993 sprawował mandat posła z ramienia Kongresu Liberalno-Demokratycznego. Był wicemarszałkiem Sejmu;

- Piotr Gliński - tworzył Partię Zielonych i działał w Wyborczej Koalicji Liderów Ekologicznych. W 1997 r. z list Unii Wolności kandydował bez powodzenia w wyborach parlamentarnych. Kandydat na premiera „rządu technicznego” Prawa i Sprawiedliwości;

- Tomasz Żukowski - doradzał między innymi Obywatelskiemu Klubowi Parlamentarnemu i Akcji Wyborczej „Solidarność”. Od stycznia 2008 r. do kwietnia 2010 był doradcą prezydenta Lecha Kaczyńskiego;

- Zdzisław Krasnodębski - w 2014 r. został członkiem rady programowej Prawa i Sprawiedliwości. W wyborach do Parlamentu Europejskiego uzyskał mandat eurodeputowanego VIII kadencji;

- Lena Kolarska-Bobińska - posłanka do Parlamentu Europejskiego VII kadencji, od 2013 r. minister nauki i szkolnictwa wyższego w rządzie Ewy Kopacz;

- Ireneusz Krzemiński - na początku lat dziewięćdziesiątych należał do Kongresu Liberalno-Demokratycznego. Bez powodzenia w 1991 kandydował z listy tej partii do Sejmu RP;

\footnotetext{
${ }^{32}$ A. Kubiak, Destrukcja procesu akulturacji badań sondażowych, w: Przegląd Socjologiczny, t. 56, z. $1 / 2007$, s. 75 .

${ }^{33} \mathrm{Na}$ rynku politycznym pojawiają się również socjologowie, którzy na dłużej związują się ze sceną polityczną. Ludwik Dorn i Andrzej Celiński to politycy, którzy w rubryce wykształcenie wpisują: socjolog.
} 
- $\quad$ Paweł Śpiewak - jako bezpartyjny kandydat w 2005 r. został wybrany z listy Platformy Obywatelskiej do Sejmu RP;

- Janusz Czapiński - w wyborach w 2001 r. bez powodzenia ubiegał się o mandat senatora jako bezpartyjny kandydat $\mathrm{z}$ ramienia SLD-UP;

- $\quad$ Andrzej Zybertowicz - w 2014 r. został członkiem rady programowej Prawa i Sprawiedliwości. W tym samym roku startował w wyborach do Parlamentu Europejskiego, nie uzyskał mandatu posła;

- Jadwiga Staniszkis - działaczka opozycji solidarnościowej. Doradzała związkowcom. W 1980 r. została zaproszona przez Międzyzakładowy Komitet Strajkowy w Gdańsku do udziału w negocjacjach ze stroną rządową. Sympatyczka braci Kaczyńskich i Prawa i Sprawiedliwości;

- $\quad$ Edmund Wnuk-Lipiński - brał udział w pracach i obradach Okrągłego Stołu. W latach 1989-1991 kierował zespołem doradców naukowych przy Obywatelskim Klubie Parlamentarnym.

Bardzo często pojawiają się medialne głosy oburzenia. „Nasz Dziennik” informuje swoich czytelników: „Monika Olejnik zaprasza do swego programu dwóch «niezależnych» socjologów - prof. Ireneusz Krzemiński staje się wręcz «Nałęczem» Donalda Tuska, dr Jacek Raciborski zajmuje się apologią Włodzimierza Cimoszewicza. Między nimi duży telebim, na którym wielka podobizna Tuska góruje nad znacznie mniejszymi Cimoszewicza i Lecha Kaczyńskiego"34.

Socjolodzy mogli mieć również wpływ na wybór Prezydenta RP. Sąd Najwyższy (postanowienie SN z dnia 4 grudnia 1995 r.) zajmował się nieprawdziwą informacją o wyższym wykształceniu Aleksandra Kwaśniewskiego. Przeprowadzony został dowód z wyników badań następujących ośrodków badania opinii publicznej (społecznej): Ośrodka Badania Opinii Publicznej (OBOP), Centrum Badania Opinii Społecznej (CBOS), Pracowni Badań Społecznych w Sopocie i „Demoskopu”. Przeprowadzony też został materiał dowodowy z opinii Instytutu Filozofii i Socjologii Polskiej Akademii Nauk oraz z opinii biegłego profesora Antoniego Sułka z Instytutu Socjologii Uniwersytetu Warszawskiego.

W preambule opracowanego przez Komisję ds. etyki w nauce PAN Kodeksu Etyki Pracownika Naukowego można przeczytać: „Naukowcy muszą być bowiem świadomi swej szczególnej odpowiedzialności względem społeczeństwa i dobra ogółu ludzkości"35.

\section{SONDAŻE W KONTEKŚCIE UWARUNKOWAŃ MEDIALNYCH I POLITYCZNYCH}

Antoni Sulek odnotował: „W Polsce po wprowadzeniu rządów demokratycznych badania sondażowe rozwinęły się tak bardzo, że opinię publiczną utożsamia się z opinią sondażową - najzupełniej błędnie, gdyż odpowiedzi na pytania ankietowe to tylko jeden ze sposobów wypowiadania się opinii publicznej. O opinii i o sondażach mówi się tak, jak gdyby istniały one poza światem mediów. A tymczasem dzisiaj opinii publicznej bez

\footnotetext{
${ }^{34}$ M. Wójcik, Sondaże kreuja rzeczywistość, „Nasz Dziennik” 20.09.2005. s. 1.

${ }^{35}$ Kodeks Etyki Pracownika Naukowego (Załącznik do uchwały Nr 10/2012 Zgromadzenia Ogólnego PAN, z dnia 13 grudnia 2012.
} 
mediów nawet wyobrazić się nie da - poprzez media opinia się wyraża, ale i przez media jest budowana" 36 .

Większość (65\%) naszego społeczeństwa interesuje się wynikami sondaży prowadzonych przez badaczy opinii publicznej. Tylko co czwarty Polak jest zdania, że są one manipulowane i nie przedstawiają prawdziwych poglądów ludzi. Do tej mniejszości zapewne docierają głosy typu: „bo próba była niewłaściwie dobrana”, „bo ankieta była tendencyjna i sugerująca”, „bo chwiejność i zmienność nastroju naszego społeczeństwa”, „bo ośrodki badań wyborczych dostają kasę, za którą robią to, czego zainteresowani oczekują”. Na przykład w pytaniu: „Czy Polakom jest dobrze czy źle?” - zależy, kto przeprowadza badania. Kiedy wskaźnik ufności konsumenckiej Głównego Urzędu Statystycznego jest na minusie, to oznacza, że wśród ankietowanych osób przeważały te niezadowolone $\mathrm{z}$ życia i sytuacji gospodarczej. $\mathrm{Z}$ kolei robione w tym samym czasie badania internetowe przez firmę AC Nielsen pokazały, że Polacy są jednym z najbardziej optymistycznych narodów Europy (wyprzedzamy m.in. Szwajcarów, Holendrów i Finów).

W większości badań i raportów pojawiających się w prasie czy telewizji istotne są brak wiedzy i nieustanne paradoksy. W kraju dowiedzieć się można między innymi, że ponad $60 \%$ respondentów nigdy nie słyszało o Organizacji Współpracy Gospodarczej i Rozwoju (OECD), mimo to $46 \%$ Polaków twierdzi, że członkostwo w niej przyniesie nam więcej korzyści niż strat. Uderzające jest przede wszystkim to, że aż $21 \%$ Polaków nie pamięta nazwy żadnej partii ${ }^{37}$. Ireneusz Krzemiński wnioskował: „Kampania wyborcza nie jest potrzebna. Polacy wiedzą już, na kogo będą głosować. Polscy wyborcy trwają z uporem przy swoich preferencjach politycznych. Z góry wiedzą, na kogo zagłosują najczęściej na tych samych polityków, których poparli w poprzednich wyborach. W polskich warunkach wybory są przede wszystkim rytualnym potwierdzeniem przez wyborców ich stałych sympatii" ${ }^{\prime 8}$.

Jednak badania i ich nieskrępowany charakter nadwyrężają lub wręcz niszczą przywództwo, zwłaszcza w systemie demokracji parlamentarnej, wielopartyjnej ${ }^{39}$. Przywódcą w istocie jest ten, który widzi lepiej, patrzy dalej i narzuca ludziom jakieś obowiązki, jakieś ciężary, przynajmniej na czas określonych reform ${ }^{40}$. W toku reform publiczne badania opinii publicznej zwykle wykazują spadek poparcia dla tych reform i wygrywa słabsza partia, słabszy partner koalicji rządowej, który nie wymaga od obywateli żadnej odpowiedzialności ${ }^{41}$. Mechanizm powstania efektu większości można opisać w kategoriach wpływu społecznego - naszej naturalnej skłonności do unikania izolacji społecznej i wiary w to, że większość ma rację ${ }^{42}$. Uleganie „głosowi większości” jest jednak bardziej prawdopodobne u osób lękowych i neurotycznych, mających obniżoną

\footnotetext{
${ }^{36}$ A. Sułek, Co Pan(i) sądzi, „Polityka” 29.08.2005, s. 36.

${ }^{37}$ A. Giza, Supermarket polityków, „Gazeta Wyborcza” 15.07.2005, s. 17.

${ }^{38}$ I. Krzemiński, Kampania wyborcza nie jest potrzebna, „Dziennik” 4.10.2007, s. 21.

${ }^{39}$ M. Ostrowski, Co nas obchodzi świat. Ściagawka na czas chaosu, Warszawa 2006, s. 133.

${ }^{40}$ Ibidem.

${ }^{41}$ Ibidem.

${ }^{42}$ A. Wieczorkowski, M. Kossowska, Kiedy idziemy za głosem większości... o wpływie sondaży przedwyborczych na wyniki wyborów, [w:] Społeczne ścieżki poznania, red. M. Kossowska, M. Śmieja, S. Śpiewak, Gdańsk 2005, s. 168.
} 
samoocenę i niski poziom poczucia kontroli, a także u osób reagujących silnym pobudzeniem w sytuacjach konfliktu poznawczego ${ }^{43}$. Sokrates mawiał, że gdyby ktoś w teatrze wezwał do powstania szewców, tylko oni by wstali. Tak samo kowali, tkaczy czy innych, stosownie do zawodu. Jeśli jednak wywołano by rozsądnych lub sprawiedliwych, powstaliby wszyscy. I największa to w życiu przeszkoda, że nierozumna większość uważa się za rozumną.

Sondaże mogą zniszczyć lub wylansować kandydata na prezydenta, zdymisjonować ministra, a nawet skasować niewygodny telewizyjny program ${ }^{44}$. Sondażownie są nieformalnymi ośrodkami władzy, bo wpływają na wyniki wyborów. Nikt nie sprawuje nad nimi kontroli ${ }^{45}$. Na początku lat dziewięćdziesiątych sondaże, które nie przewidywały trafnie wyników wyborów (np. w 1991 r. wykazały zawyżone notowania Unii Demokratycznej), utwierdziły polityków w przekonaniu, że instytuty kierują się swoimi sympatiami politycznymi i pracują tam bądź politycy Unii Demokratycznej, bądź postkomuniści ${ }^{46}$. W związku z tym instytuty ,sekują" prawicę i przyznają w sondażach nadreprezentację polityczną tamtym środowiskom. W polskich sondażowniach rządzą ludzie z (...) CBOS (... $)^{47}$. Dziś zasiadają we władzach OBOP, Pentora, PBS i IPSOS ${ }^{48}$. Stworzyli też od podstaw GfK Polonia ${ }^{49}$.

Podczas wyborów do Europejskiego Parlamentu w 2005 r.: PBS dawał Platformie Obywatelskiej $30 \%$, ostatecznie dostała $24,1 \%$. Natomiast CBOS przewidział zwykle nieoszacowanej partii LPR $8 \%$, a ten dostał 15,92\%. Za to ten sam ośrodek KPEiR dawał $5 \%$, gdy ta ostatecznie otrzymała 0,8\%. Według Pentora Samoobrona powinna mieć $23 \%$, gdy podczas wyborów skończyli na 10,78\%. EOS Gallup Europe dawało przeważnie przeszacowanej w sondażach UW $2 \%$, a partia dostała 7,33\%.

Im bliżej wyborów zazwyczaj nasila się liczba protestów. Komitet Wyborczy profesor Marii Szyszkowskiej protestował przeciw komentarzowi zamieszczonemu w Rzeczpospolitej - „Nikt nie chce głosować na Marię Szyszkowską”. W swym proteście Komitet Wyborczy fachowo zauważył: „Wynika stąd, że respondenci biorący udział w sondażu «Rzeczypospolitej» nie są grupą reprezentatywną, a - być może - specjalnie dobraną grupą osób, mającą potwierdzić konkretne założenia sondażu”.

Z Ligi Polskich Rodzin Romana Giertycha można było usłyszeć, że media publiczne nie publikują Polskiej Grupy Badawczej (PGB), która poprzednio występowała pod nazwą Ośrodek Badań Wyborczych. Na wyniki PGB powołuje się głównie prawica, która wypada tam znacznie korzystniej. Dla „Gazety Wyborczej” badania ankietowe OBW to „dowolnie wymyślane liczby”. Najlepszą metodą jest założyć własny ośrodek badawczy, w którym wygrywałaby partia lub jej lider związany ze swoim własnym ośrodkiem. Prawo i Sprawiedliwość ma własne badania opinii publicznej, najlepiej wierzyć we własne sondaże. Tak też uczyniła Samoobrona, tworząc Centrum Analiz Wyborczych, w których nie trzeba dodawać, kto ma największe poparcie. Inną niezależną pracownią jest

\footnotetext{
${ }^{43}$ Ibidem.

${ }^{44}$ P. Lisiewicz, Grupa trzymająca sondaże, „Gazeta Polska” 13.12.2006.

${ }^{45}$ M. Mikołajczyk, Czarodzieje opinii publicznej, „Nie” 2005/41.

${ }^{46}$ L. Kolarska-Bobińska, Rola sondaży w procesie politycznym, w: Przegląd Socjologiczny, t. 56, z. 1/2007, s. 31.

${ }^{47}$ P. Lisiewicz, op. cit.

48 Ibidem.

${ }^{49}$ Ibidem.
} 
Narodowe Centrum Badania Opinii, gdzie zasada doboru próby jest prosta. Przepytuje się przypadkową grupę osób, zgromadzoną wokół stolików z ankietami. Zatwardziali w swych błędach polscy politycy szukają winnych wszędzie tylko nie w swym własnym gronie $^{50}$.

Na temat ,ustawianych sondaży” wypowiedział się Tomasz Żukowski podczas wywiadu:

„- Czy zna pan przypadki ustawionych sondaży politycznych?

- Sądzę, że znam.

- Co to były za badania?

- Nie powiem, bo nie mam dowodów, tylko poszlaki, a poza tym nie chcę tracić czasu w sądowych poczekalniach. W każdej branży są lepsi i gorsi, bardziej i mniej uczciwi"

Eryk Mistewicz rzuca podejrzenie na wyniki kreowane przez sondaże: „Kiedyś w kampaniach stawiano na bilbordy, dziś na publikowanie sondaży. To o wiele tańsza forma propagandy. Sondaż, potwierdzający najbardziej kpiącą z inteligencji odbiorcy tezę, można zamówić już za cenę dwóch - trzech billboardów. [...] Część ośrodków badawczych to dziś tzw. mainstream medialny w jego najgorszym wydaniu",52. Ważną rolę odgrywają koszty, gdyż przeprowadzenie sondażu jest stosunkowo tanie, ceny zaczynają się już od kilku tysięcy złotych. Dla partii dysponujących każdego roku $30 \mathrm{mln}$ złotych z budżetu, a nawet tych mających do dyspozycji jedynie $8 \mathrm{mln}$ zł - nie jest to w ogóle wydatek ${ }^{53}$. Prezes OBOP Andrzej Olszewski na temat finansowania badań wyraził się następująco: „Mamy jedne z najtańszych badań w całej Europie, już chyba tylko Albania jest tańsza niż Polska. Mamy aspiracje być w G20, a jesteśmy na 48. miejscu, jeżeli chodzi o poziom cen na świecie według zestawienia ESOMAR. [...] Przykład z ostatnio rozstrzygniętego przetargu dla jednego $\mathrm{z}$ dużych miast: nasza oferta wynosiła około 240 tys. zł, w tym same koszty ankieterskie to ponad 120 tys. zł. Tymczasem wygrała firma z ofertą około 70 tys. zł. Tam nie ma miejsca na jakość!" 54 .

Problem pojawia się też $\mathrm{z}$ pracą ankietera w terenie. Janusz Czapiński: „Jestem pewien, że jeżeli zapuka do drzwi zwolenników Radia Maryja, nikt mu nie otworzy. W rezultacie nie ma więc wyników z tej próby i nie wiemy, czy ci ludzie w ogóle pójdą na wybory” ${ }^{5}$. Radosław Markowski: „Problem w tym, że ci, z którymi nie udaje się nam porozmawiać, wypadają z próby nie przypadkiem, lecz dlatego że mają konkretne cechy. Dotyczy to często ludzi względnie młodych, wykształconych i aktywnych zawodowo. Takich, których trudno zastać w domu, którzy mają mało czasu" 56 .

Coraz częściej, także w Polsce, wraz z nadprodukcją badań społecznych gubimy się w tym, kto w społeczeństwie formułuje niezależne dziewicze opinie, a kto reaguje na podane

\footnotetext{
${ }^{50}$ P. Gliński, Skrzywianie zwierciadta, „Rzeczpospolita” 13.10.2005, cyt. za: Publicystyczny komentarz socjologów. Analiza. Polemiki. Wywiady, red. H. Domański, A. Ostrowska, Warszawa 2006, s. 130.

${ }^{51}$ T. Żukowski, W strefie obciachu, wywiad z Igorem Janke, „Rzeczpospolita” 15.06.2010.

${ }^{52}$ E. Mistewicz, Sondaze to wielka bzdura, „Fakt” 8.06.2010, s. 3.

${ }^{53}$ E. Mistewicz, Sondaże: w to graja już wszyscy, „Uważam Rze” 2011/3.

${ }^{54}$ A. Olszewski, Sondaże nie sa wyrocznia, wywiad z Jarosławem Stróżykiem, „Rzeczpospolita” 12.07.2010.

${ }^{55}$ A. Laskowska, Ankieter strzela sobie w teb, ,Angora” 30.09.2007/39, s. 15.

${ }^{56}$ R. Markowski, W szponach sondaży, Niezbędnik inteligenta, „Polityka” 11.12.2004/50, s. 39.
} 
przez media gotowce i na ile opinia taka staje się po prostu reakcją na wynik sondażu ${ }^{57}$ ? Teoria „spirali milczenia” - i roli mediów w nakręcaniu tej spirali - sprawdziła się w Polsce wiele razy, od początku lat dziewięćdziesiątych, i zawsze w tej samej konfiguracji: respondenci $\mathrm{w}$ badaniach deklarowali gotowość popierania partii lub kandydata sławionego przez tak zwane opiniotwórcze media - w latach dziewięćdziesiątych oznaczało to „Gazetę Wyborczą" - a potem szli na wybory i głosowali na kogoś zupełnie innego $^{58}$. Pojawił się też okres w TVP z próbą zakazu sondaży politycznych. Emitowany w TVP Info publicystyczny program Forum nie mógł prezentować sondaży poparcia dla partii. Argumentowano, że sondaże przedwyborcze są niepotrzebne i w dodatku fałszują obraz rzeczywistości ${ }^{59}$. Bardzo się można było zdziwić, gdy w pierwszej połowie roku rankingi polityków zniknęły z serwisów $\mathrm{TVP}^{60}$. Powód był prosty - notowania SLD i rządu spadały ${ }^{61}$

Jacek Żakowski niejednokrotnie zgłaszał uwagi dotyczące błędów i manipulacji. W 2013 r. radio Tok.fm przedstawiło uwagi do programu Faktów TVN oraz firmy sondażowej Millward Brown SMG/KRC. Przedmiotem dziennikarskiej analizy był sondaż prezentujący, kto powinien zostać premierem Polski, w którym Polacy wybrali Jarosława Kaczyńskiego (18\%). Żakowski zauważył, że inni politycy: Donald Tusk (13\%), Jerzy Buzek (135), Grzegorz Schetyna (7\%), Jarosław Gowin (8\%), Leszek Miller (9\%), mają w sumie większe poparcie niż prezes PiS i prosił o interwencję. Pojawił się też problem innych badań związanych z tzw. „Raportem Komisji Milera”. Jacek Żakowski pytał: „Co mieli na myśli goście z radia, nadając wynikom sondażu tytuł «Raport nie przekonał co drugiej osoby»? Równie dobrze mogli zapytać Polaków, czy ich przekonuje najnowszy program koreańskiej partii komunistycznej”. Publicysta analizował skomplikowany $\mathrm{i}$ trudny $\mathrm{w}$ odbiorze raport, ponadto przedstawiany $\mathrm{w}$ ciągu dnia roboczego. Na zlecenie Polskiego Radia współpracujący z nim stale Instytut Homo Homini zapytał telefonicznie „reprezentatywną grupę Polaków”: „Czy Pana/Pani zdaniem raport komisji Jerzego Millera ostatecznie wyjaśnia przyczyny katastrofy smoleńskiej?”. [...] Zanim badanie zostało wymyślone, zlecone, wykonane i opublikowane, można było ze stuprocentowym prawdopodobieństwem przyjąć, że ponad $80 \%$ pytanych nie będzie miało bladego pojęcia, o czym mówią. [...] Gdyby sondaż dotyczył czyichś włosów na plecach albo tego, kto ma zgrabniejsze nogi - Kaczyński czy Komorowski - to bym się nie wściekał"62.

Jedna z bardzo głośnych wpadek wydarzyła się w 2006 r. - 18 września 2006 CBOS prostował wyniki sondażu na temat korupcji wśród polityków. Badanie przeprowadzone na zlecenie Fundacji im. Batorego przeprowadził CBOS. Raport z badania opublikowano 5 września w siedzibie Fundacji. Z raportu wynikało, że za najbardziej skorumpowane partie respondenci uznali: PiS (35\% wskazań), Samoobronę (10\%), LPR (9\%), PO (9\%), SLD $(8 \%)$ oraz PSL $(3 \%)$. Winowajcą okazał się błąd informatyczny $w$ trakcie prac obliczeniowych, który spowodował przedstawienie nieprawdziwych danych na temat partii. Według prawdziwych danych na pierwszym miejscu znalazły się: Samoobrona i

\footnotetext{
${ }^{57}$ Ibidem, s. 41

${ }^{58}$ A. Wołk-Łaniewska, W stupki wierza gtupki, „Nie” 2010/227, s. 11

${ }^{59}$ S. Kucharski, Magazyn „Forum” bez sondaży?, „Rzeczpospolita” 22.05.2009.

${ }^{60}$ R. Murski, Gra w procenty, „Gazeta Wyborcza” 14.10.2002, s. 20.

${ }^{61}$ Ibidem

${ }^{62}$ J. Żakowski, Nieprzekonani, „Gazeta Wyborcza” 01.08.2011.
} 
SLD (po 2,8\% wskazań), a na dalszych miejscach: PiS (1,47\%), LPR (0,94\%), PO (0,7\%) i PSL $(0,1 \%)$. Prawo i Sprawiedliwość zostało przeproszone. Informacja o skorumpowanym PiS-ie to był tak zwany hard-news. Natomiast przeprosiny pojawiły się na przykład w „Gazecie Wyborczej” na stronie dziewiątej ${ }^{63}$. Jednak medialni eksperci zdążyli na łamach prasy się wypowiedzieć i komentować („Badani postrzegają PiS jako partię rządzącą, więc obarczają ją odpowiedzialnością za sytuację”, „Zawsze tych, którzy aktualnie rządzą, obwiniamy o największe chciejstwo i brak czystości moralnej. Bo przecież odsunięte od władzy PiS nie miałoby takich możliwości jak teraz”, „Hasła PiS o walce $\mathrm{z}$ korupcją były fajne w kampanii wyborczej. Tak naprawdę jednak żadnej walki nie ma").

Podsumowując, warto nadmienić, że w polskich pracach metodologicznych głównych źródeł błędów w badaniach surveyowych upatrywano we wszystkich etapach procesu badawczego $^{64}$ :

1. Wady doboru i realizacji prób reprezentacyjnych.

2. Czynniki zakłócające wiarygodność wypowiedzi w wywiadzie związane z: (a) samym narzędziem badawczym (kwestionariuszem); (b) prowadzącym wywiad (ankieterem), a także (c) sytuacją rozmowy, interrogacją.

Czynniki zakłócające właściwe wykorzystanie wypowiedzi udzielonych w wywiadzie, związane z: (a) interpretacją (rozumieniem) wypowiedzi respondenta oraz (b) transkrypcją (kodowaniem).

\section{LITERATURA}

[1] Bachmann K., Utajnione ankiety, Dole i niedole OBOP, Pomocnik historyczny, „Polityka” 16.08.2008/33.

[2] Bartoszewski W., Za dtugo żyję na tym świecie, żeby ślepo wierzyć przedwyborczym sondażom, „Dziennik” 6.10.2007.

[3] Bielecka-Prus J., Spoteczne role socjologów w PRL, „Przegląd Socjologiczny” 2/58 (2009).

[4] Bourdieu P., Exposé wygłoszone w styczniu 1972 r. w Centrum Kultury Noroit w Arras, „Les Temps Modernes” 1973/318 [polska wersja tekstu dostępna W Czytelni „Nowej Konfederacji”, tłum. A. Rybińska].

[5] Dyoniziak R., Dylematy upaństwowionej socjologii, „Akademia Ekonomiczna w Krakowie. Zeszyty Naukowe" 2001/566.

[6] Flis A., Wyzwania wobec nauk społecznych, Kraków 1999.

[7] Galus H., Rola socjologii nauki i polityki w życiu publicznym, Gdańsk 2007.

[8] Giza A., Supermarket polityków, „Gazeta Wyborcza” 15.07.2005.

[9] Gliński P., Skrzywianie zwierciadta, „Rzeczpospolita” 13.10.2005, cyt. za: Publicystyczny komentarz socjologów. Analiza. Polemiki. Wywiady, red. H. Domański, A. Ostrowska, Warszawa 2006.

[10] http://ninawinczewska.blox.pl/2014/07/Teoria-spirali-milczenia.html, 12.11.2014.

\footnotetext{
${ }^{63}$ A. Kublik, Wpadka CBOS. PiS przeproszone, Gazeta Wyborcza, 19.09.2006, s. 9.

${ }^{64}$ K.M. Słomczyński, Polska metodologia socjologicznych badań empirycznych na tle międzynarodowym, [w:] Nowe metody, nowe podejścia badawcze w naukach spotecznych, red. P.B. Sztabiński, F. Sztabiński, Z. Sawiński, Warszawa 2004, s. 16.
} 
[11] http://3obieg.pl/manipulacja-wg-chomskyego, 15.12.2014.

[12] Iłowiecki M., Krzywe zwierciadto. O manipulacji w mediach, Lublin 2003.

[13] Kodeks Etyki Pracownika Naukowego, Załącznik do uchwały Nr 10/2012 Zgromadzenia Ogólnego PAN, 13 grudnia 2012.

[14] Kolarska-Bobińska L., Rola sondaży w procesie politycznym, „Przegląd Socjologiczny" LVI/1 (2007).

[15] Krzemiński I., Kampania wyborcza nie jest potrzebna, „Dziennik” 4.10.2007.

[16] Kubiak A., Destrukcja procesu akulturacji badań sondażowych, „Przegląd Socjologiczny" LVI/1 (2007).

[17] Kublik A., Wpadka CBOS. PiS przeproszone, Gazeta Wyborcza 19.09.2006.

[18] Kucharski S., Magazyn „Forum" bez sondaży?, „Rzeczpospolita” 22.05.2009.

[19] Kurczewski J., Bauman optymista, „Gazeta Wyborcza” 22.11.2010.

[20] Kwiatkowski S., Szkicownik z CBOS-u: Rysunki socjologiczne z tamtych lat, Tyczyn 2004.

[21] Laskowska A., Ankieter strzela sobie w teb, „Angora” 30.09.2007/39.

[22] Lisek-Michalska J., Wybrane problemy sondażowych badań opinii publicznej w Polsce w okresie przełomu ustrojowego, w: Analizy i próbki technik badawczych w socjologii, Sondaże opinii społecznej. Samowiedza wspótczesnych społeczeństw, red. Z. Gostkowski, P. Daniłowicz, t. X, Łódź 2001.

[23] Lisiewicz P., Grupa trzymająca sondaże, „Gazeta Polska” 13.12.2006.

[24] Lutyńska K., Wywiad kwestionariuszowy. Przygotowanie i sprawdzanie narzędzia badawczego, Warszawa 1984.

[25] Markowski R., W szponach sondaży, Niezbędnik inteligenta, „Polityka” 11.12.2004/50.

[26] Mikołajczyk M., Czarodzieje opinii publicznej, „Nie” 2005/41.

[27] Mistewicz E., Sondaże to wielka bzdura, „Fakt” 8.06.2010.

[28] Mistewicz E., Sondaże: w to graja już wszyscy, „Uważam Rze” 2011/3.

[29] Murski R., Gra w procenty, „Gazeta Wyborcza” 14.10.2002.

[30] Noelle- Neumann E., Spirala milczenia, Poznań 2004.

[31] Olszewski A., Sondaże nie sa wyroczniq, wywiad z Jarostawem Stróżykiem, „Rzeczpospolita” 12.07.2010.

[32] Ostrowski M., Co nas obchodzi świat. Ściagawka na czas chaosu, Warszawa 2006.

[33] Sommer H., Komunikowanie sie w przedsiębiorstwie, Zeszyty Naukowe Politechniki Rzeszowskiej, Ekonomia i Nauki Humanistyczne (aktualna nazwa Humanities and Social Sciences) z. 14, nr 219, 2004; s. 167-185

[34] Staszewski K., Sondażomania, w: Niepiosenki, Warszawa 2008.

[35] Stecko J., Kultura zaufania jako fundament społecznego życia etycznego [w:] Zaufanie $w$ życiu publicznym, (pod red.) Władysław Zuziak, Joanna Mysona Byrska, s.163-174, Kraków 2014.

[36] Słomczyński K.M., Polska metodologia socjologicznych badań empirycznych na tle międzynarodowym, w: Nowe metody, nowe podejścia badawcze w naukach społecznych, red. P.B. Sztabiński, F. Sztabiński, Z. Sawiński, Warszawa 2004.

[37] Sułek A., Ogród metodologii socjologicznej, Warszawa 2002.

[38] Sutek A., Walka o wolność publikacji wyników sondaży wyborczych w Polsce, „Przeglad Socjologiczny” LVI/1 (2007).

[39] Sułek A., Co Pan(i) sadzi, „Polityka” 29.08.2005. 
[40] Szczepański S., Socjologia a fuszerka socjologiczna, „Przegląd Kulturalny” 1960/13, cyt. za: Publicystyczny komentarz socjologów. Analiza. Polemiki. Wywiady, red. H. Domański, A. Ostrowska, Warszawa 2006.

[41] Wieczorkowski A., Kossowska M., Kiedy idziemy za głosem większości... o wptywie sondaży przedwyborczych na wyniki wyborów, [w:] Społeczne ścieżki poznania, red. M. Kossowska, M. Śmieja, S. Śpiewak, Gdańsk 2005.

[42] Wołk- Łaniewska A., W stupki wierza głupki, „Nie” 2010/227.

[43] Wójcik M., Sondaże kreują rzeczywistość, „Nasz Dziennik” 20.09.2005.

[44]Żukowski T., W strefie obciachu, wywiad z Igorem Janke, „Rzeczpospolita” 15.06.2010.

[45]Żakowski J., Nieprzekonani, „Gazeta Wyborcza” 01.08.2011.

\section{ELECTION SURVEYS - SOCIOLOGY AT THE SERVICE OF THE POLITICS}

Before every elections we are being inspired from every side with election surveys telling us which candidate or which party what support has. Forecasts in the media have one aim of showing us for spectators strong support for a party to which our voice won't be wasted because for every to vote in favour of the grouping which supporting the electoral threshold on the border has since aren't having chances to change nothing or this way won't cross border of electoral threshold. Critics are raising, that the level would not be ashamed of the propaganda of both the manipulation of today's so-called free media and surveys demonstrated by them champions of the propaganda. The most frequent survey errors appear around such problems as; keeping unsure electors casting a vote in choices to the candidate, of which supporting in surveys is highest. The elector in the last moment is changing his mind and a vote for the candidate for which he didn't intend to vote which turned out to be the leader in results of surveys is conveying. The majority of our society is interested in results of surveys announced by opinion pollsters. The minority is holding a view that they are manipulated and aren't showing real views of people. In a deluge of information, however citizens aren't analysing methodological properties, associated with the appropriately selected attempt or the correctly constructed questionnaire of the questionnaire form. Grabbing balancing of electors hold of and moodinesses of respondents, especially in the election year is posing a challenge for research centres. Extremely an attempt seems interesting to the answer to a question for affecting the outcome of the election, directing views of chief actors of the political landscape, as well as personal, political commitment of researchers and commentators of the Polish politics.

Keywords: politics, sociologists, public opinion, surveys.

DOI:10.7862/rz.2015.hss.13

Przesłano do redakcji: listopad 2014

Przyjęto do druku: maj 2015 